Erik Knain er postdoktor i halv stilling ved Institutt for lærerutdanning og skoleutvikling (ILS) ved Universitetet i Oslo, og er prosjektleder for IKT i naturfag ved Seksjon for læring og lærerutdanning ved Universitetet for milj $\phi$ - og biovitenskap. Hans forskning har fokusert på tekst i vid forstand, blant annet på ideologier i lærebøker i naturfag og elevenes bruk av læreb $\varnothing$ ker, og identitetsaspekter ved skriving i naturfag.

\title{
Skriving i naturfag: mellom tekst og natur
}

\begin{abstract}
Writing will be a basic skill in the new curriculum now being developed in Norway. This implies that writing should be learned by students in every school subject, including science. It should be welcomed, as writing is a key activity in both professional and school science. However, there are some key issues that need to be addressed: the relationship between process and product, between tacit and explicit knowledge and between nature and text. Thus writing introduced as a basic skill reintroduces key issues and dilemmas in science education while at the same time holds promise for a functional conception of 'scientific literacy'.
\end{abstract}

\section{INNLEDNING}

I de framtidige læreplanene for grunnopplæringen vil skriving være en av flere grunnleggende ferdigheter, fastslått bl.a. i statsrådens foredrag i åpningen av læreplanarbeidet (se http://www. utdanningsdirektoratet.no/). De grunnleggende ferdighetene er nærmere beskrevet i Stortingsmelding 30 "Kultur for læring" (UFD, 2003-2004), og omfatter å kunne uttrykke seg muntlig, å kunne lese, å kunne uttrykke seg skriftlig, å kunne regne, og å kunne bruke digitale verktøy. Disse grunnleggende ferdighetene skal nedfelles i ulike fag i planarbeidet som pågår i skrivende stund. I St. mld. 30 blir de grunnleggende ferdighetene knyttet til 'literacy' tradisjonen, som har flere retninger (Berge, 2004).

Dette gjør det nødvendig sette tekst og skriving i naturfag på dagsorden. På mange måter er det i utgangspunktet en takknemlig oppgave, siden skriving allerede er viktig både i naturfag og naturvitenskap. Norris og Phillips (2003) slår fast at naturvitenskapelig virksomhet på en helt grunnleggende måte er en tekstlig aktivitet, kumulativ kunnskapsutvikling ville ikke vært mulig uten tekst. I naturfag vil et fokus på tekst også omfatte funksjonelle leseferdigheter, som å kunne kritisk vurdere hensikter i teksten. Naturfaglige kunnskaper er nært knyttet til lese- og skriveferdigheter.

Denne artikkelen vil fokusere på skriving i naturfag. Hvordan kan skriving støtte læring i naturfag? Generelt kan elever lære gjennom språk, lære om språk, og lære å bruke språk (Christie i Prain (2004)). I det første tilfellet er språket en ressurs for å lære faglige begreper og grammatiske mønstre, med hverdagsspråket som utgangspunkt. I det andre tilfellet studerer elever språket som system; hva som kjennetegner naturfaglig språk, hvilke muligheter og begrensninger har dette språket, hvilke verdier rommer det. I det tredje tilfellet handler det om å kunne lese, snakke og skrive språket kompetent i ulike situasjoner, med ulike hensikter og for ulike mottakere. 
En gjennomgang av engelskspråklig litteratur omkring skriving i naturfag gjort av Wallace (2004) peker i generelle vendinger mot at skriving gir økt læringsutbytte i naturfag. Både begrepsforståelse og metakognisjon blir fremmet gjennom skriving. I norsk sammenheng har Valdermo og Eilertsen (2002) pekt på strategier for å utvikle elevenes læringsvaner basert på utviklingsarbeid i skolen, hvor ulike former for skriving utgjør viktige strategier. Wallace diskuterer også hvorvidt elever kan lære naturfaglige skrivemåter, eller sjangere. Barn begynner å tilegne seg sjangere $\mathrm{i}$ veldig ung alder. Men å lære å skrive i naturfagets sjangere faller ikke like lett for elever som den mer uformelle, eksplorerende skrivingen i følge Wallace: Ofte blir bruken 'hul' med mangler i det substansielle innholdet når elevene forsøker å anvende tilbudte sjangeroppsett. Dette blir diskutert særskilt nedenfor.

Denne artikkelen søker å trekke opp et lerret av perspektiver på skriving i naturfag og reise noen problemstillinger knyttet til fagets selvforståelse. Den vil i liten grad berøre konkrete undervisningsopplegg i naturfag. Slike finnes det imidlertid mange av i litteraturen (for eksempel Thier og Daviss (2002) og Osborne og Wellington (2001)). Mange undervisningsressurser finnes også på internett. Denne artikkelen er heller ingen review-artikkel. Den vil i større grad fokusere på noen forhold som er viktige for valg og implementering av strategier i naturfagundervisning.

\section{Perspektiver PÅ SKRIVING I NATURFAG}

Skriving i naturfag kan trekkes opp langs en akse som defineres av to hovedposisjoner eller rasjonaler for skriving. Å trekke opp denne aksen er i utgangspunktet en upresis øvelse, siden ulike betegnelser rommer både ulike teoritradisjoner, historiske utviklingslinjer og institusjonelle forankringer. En bred retning er Writing Across the Curriculum-bevegelsen (WAC). Fra opprinnelsen som mange knytter til Brittons (1970) Language and Learning, har WAC etter hvert fått et sterkt innslag av Writing to Learn (Connolly, 1989), her kalt Skrive for å lære. Et fokus på skriving som prosess kan også rotfestes i denne tradisjonen. En annen retning, tydeligst representert av (den australske) sjangerskolen grunnlagt av Halliday, kan betegnes for Lære å skrive (Prain, 2004). Sistnevnte vil høre inn under en Writing In the Disciplines (WID) paraply. Grensegangene her er imidlertid utydelige, siden retninger i WID utviklet seg i WAC. WAC går også under betegnelsen 'uformell' skriving i forhold til WIDs fokus på fagdisiplinenes sjangere. Disse posisjonene har altså flere betegnelser, og det er nyanser i hva som vektlegges i litteraturen. Keys (1999) skiller mellom ekspressiv skriving som bruker hverdagslivets språk for refleksjon for å forklare ting for en selv, og transaksjonell skriving rettet mot å informere.

Den utviklingen i betegnelser som er trukket opp sier en del om fokuset og grunnlaget i disse retningene, og kan oppsummeres i denne tabellen. Tabellen under er et omriss for diskusjonen som følger, selv om ikke alle celler i tabellen blir adressert direkte.

\begin{tabular}{|l|l|}
\hline Skrive for å lære & Lære å skrive \\
\hline Lære gjennom språk & Lære å bruke språk \\
\hline Writing Across the Curriculum & Writing in the Disciplines \\
\hline Skrive for å reflektere, forstå & Skrive for å kommunisere, informere \\
\hline Ekspressiv, eksplorerende & Transaksjonell \\
\hline Hverdagslivets språk, uformell & $\begin{array}{l}\text { Sjangrene: disipliner (funksjonelle } \\
\text { tekstnormer), sjangere som palett }\end{array}$ \\
\hline Prosess & $\begin{array}{l}\text { Produkt/ transaksjon (system av } \\
\text { produkt) }\end{array}$ \\
\hline \multicolumn{2}{|c|}{ Teknologimestring: håndverket, ferdigheten } \\
\hline
\end{tabular}




\section{SKRIVE FOR Å LARE NATURFAG}

Et kjernepunkt i denne retningen er et fokus på hverdagsspråket som det primære utgangspunktet for læring og redskap for å forstå fagstoff. Det hverdagslige språket er elevenes eget, knyttet til hverdagslige gjøremål og uformelle situasjoner. Elevene skal kunne reflektere uten ytre føringer eller prestasjonskrav.

There is a profound difference between the preliminary use of language to serve thinking and the ultimate display of thought that we call disposition or argument. [...] Informal writing is done independently of, or at least prior to, any formal writing assignments in a course. It is unconstrained by a need to appear correctly in public. It is not yet deliberately arranging, asserting, or arguing. It is still reflecting and questioning (Connolly, 1989, s 6).

Men dette betyr ikke at denne typen skriving er fremmed for 'det faglige', tvert i mot så skal den utvikle skrivekompetanser som er viktige i faget; Connolly lister opp en rekke evner (definere, klassifisere, analysere, lage hypoteser, finne mønstre), metoder (lesestrategier, nedtegne data, lage teori, reflektere over metode), i tillegg til kunnskaper og holdninger. Dessuten skal elevene lære å samarbeide om læring gjennom at elevene diskuterer "åpent" og fokusert på egen forståelse (Connolly, 1989, s 7).

Dette er en type skriving som skal skje på elevenes hjemmebane i språket, og som er orientert mot prosess, ikke produkt. Også i naturvitenskap er det ulike måter å bruke språk på når forskerne spekulerer og diskuterer sammenlignet med når påstander om at 'slik er det' blir lagt fram. Mer varierte former for skriving er nødvendig for å forstå naturvitenskapelige prosesser, både internvitenskapelige og naturvitenskap som del av et samfunn.

Keys (1999) har imidlertid imøtegått en underforstått premiss i denne retningen at et fokus på sjanger i skriveopplæringen samtidig er et fokus på produkt på bekostning av prosess. Dette imøtegår hun ved å framheve naturfaglige sjangere som omgivelser for refleksjon i et funksjonelt sjangerperspektiv.

\section{LAERE ̊̊ SKRIVE NATURFAG}

\section{Et funksjonelt perspektiv}

For både å illustrere det funksjonelle perspektivet og et viktig aspekt ved naturvitenskapelig språkbruk, skal vi ta utgangspunkt i setningen

Under oppvarmingen skjer det en energioverføring fra energikilden til energimottakeren

hentet fra en lærebok. Denne setningen er en konkretisering av begrepet:

energikjede

Hvis vi ser på overgangen fra setningen til begrepet, så ser vi at begrepet mangler de grammatiske aspektene tid, handling og aktører. Det er en grammatisk overgang fra at noe skjer (setning med verb og aktører) til 'ting'. Dette kalles en nominalisering. Nominaliseringen innebærer at begrepet har blitt både destillert og samtidig mer generelt. Nettopp derfor er nominaliseringer viktige for to viktige funksjoner i naturvitenskapelig språk: Teoribygging og argumentasjon. De muliggjør en diskurs hvor nye kunnskapselementer kan utvikles fra etablerte gjennom at kjent og ny informasjon kan veksle gjennom en skriftlig tekst.

Disse trekkene ved naturvitenskapelig språk ble utviklet samtidig med en gryende institusjonalisering av den framvoksende naturvitenskapen, og dette kan knyttes konkret til dannelsen av The Royal Society of London (se Knain og Flyum (2003) for en framstilling sammen med en diskusjon 
av sjangerbegrepet). Naturfagets sjangere har blitt til gjennom en historisk utvikling som svar på naturviternes behov - nye måter å forstå verden på og metoder for å få kunnskap om den på gjorde at de ikke bare utviklet nye begreper, men også tok i bruk tilgjengelige grammatiske mønstre for nye formål.

Halliday og hans kolleger har gjort mange studier av naturvitenskapens språk (Halliday og Martin, 1993), og på grunnlag av disse utviklet pedagogiske programmer i australsk skole som først var ment for under-priviligerte elevgrupper, men som også ble benyttet mer generelt i skolen.

Gjennom å beskrive eller forklare i fagets problemområder lærer elevene begreper, teorier og klassifiseringer som er viktige i faget. Kanskje er det denne virkelighetsbeskrivende delen av språket som vi klarest forbinder med naturfag (hvor 'virkeligheten' kan være idealisert, abstrakt, fiktiv osv.). Men denne læringen er ikke et rent individuelt anliggende. Gjennom interaksjon med medelever, lærere og utstyr lærer elevene noe sammen med de faglige kunnskapene om hva det vil si å arbeide naturfaglig gjennom de hensikter tekstene tjener for elever og lærere i de naturfaglige aktivitetene, som naturfaglig sjanger.

Written genres constitute the culturally developed ways of carrying out certain rather general communicative actions to achieve particular types of goals or purposes in the context of the relevant overarching activities (Wells, 1999, s 152).

Sjangeren er et semiotisk verktøy som læres - som andre verktøy - best gjennom utøvelsen i de faglig relevante sammenhengene. Sagt med Lemke, "semiotic practices are actions that make sense in a community" (Lemke, 2001, s 187). I sjangeren ligger det med andre ord konvensjoner for å skrive naturfaglig. Naturfaglig sjangere utgjør dermed et sett med generelle skriftspråklige kompetanser rettet mot noen hovedfunksjoner som skriving har i naturfaglig skriving ${ }^{1}$.

\section{Sjanger som vei til å synliggjøre naturfagets kultur}

Sjangerretningen har vektlagt det å gjøre naturfaglig språk, og dermed fagets kultur og tenkemåter, tilgjengelig for elevgrupper som ikke uten videre oppnår denne deltakelsen i naturfaglige skriftkulturer gjennom taus kunnskap og normopptak gjennom praksis. Gjennom studier av teksteksempler bevisstgjøres elever på grammatiske trekk ved sjangere, og hva elevene tilegner seg gjennom dem. På en måte kan en si at denne retningen faktisk gjør grensekrysning til naturfagets 'subkultur' synlig for elever som opplever krysningen problematisk, i tråd med Coberns og Aikenheads perspektiver (1998). En viktig forskjell er imidlertid at mens Cobern og Aikenhead mener at elever som er grunnleggende fremmed for naturvitenskapelig verdensanskuelse ikke skal "tvinges" til å bruke dens redskaper på fenomener og problemstillinger, så trekker ikke sjangerpedagogene opp noen prinsipiell forskjell mellom målsetningen for elever som er fortrolige med naturfaglige skriftkulturer og de som strever med å forholde seg til denne subkulturen. Naturfagets sjangere er viktige kulturelle verktøy for alle. Og de kan ikke erstattes av narrative skrivemønstre. "Factual genres do not grow out of narrative, but have their own roots in spoken and written language whose function is to explore the world" (Martin, 1993, s 194).

\section{LAERING SOM TRANSFORMASJON AV TEKST}

For å imøtekomme kritikk mot sjangertilnæringen for at prosessdimensjonen ved skriving blir neglisjert blir det viktig å forstå hva det dynamiske aspektet ved skriving består i, og at dette omsettes til praksis.

\footnotetext{
${ }^{1}$ Naturvitenskapen vil være en viktig referanseramme for naturfag, men naturfag er en omforming av naturvitenskap til andre deltakere og hensikter, og foregår i en annen institusjonell ramme. Det vil derfor være betydelige forskjeller mellom dem, men også likheter.
} 


\section{Det dynamiske aspektet: Kress}

Hvis sjangerskriving blir redusert til å reprodusere ferdige sjablonger, så har den blitt sin egen parodi, og elevene mister det funksjonelle aspektet. La oss derfor se mer prinsipielt hva et slikt dynamisk element kan bestå i.

Johns (2002) påpeker at sjangere er i stadig utvikling, fordi

1. Sjangere utvikler seg for å møte endrede sosiokognitive behov i diskurser.

2. Sjangere utvikler seg i møte med ny teknologi.

3. Sjangere utvikler seg gjennom endringer i ideologi og verdensanskuelser i skriftkulturer.

4. Sjangere endrer seg gjennom at individer bryter tekstlige konvensjoner. (Johns, 2002, s 239).

Det er viktig å skille mellom et kulturelt og institusjonelt nivå i forhold til situasjonen; dette er ulike nivåer av mening og tidsskalaer. Situasjonen utgjør en kortere tidsskala enn det kulturelle og institusjonelle nivået som sjangrene hører til under. Det gjør dels at sjangere er 'seige', de motstår i noen grad endring. Samtidig vil noe av sjangerens normer og mulige identiteter gjøres til elevenes egne i situasjonen, med det resultat at 'noe' endres i eleven. I denne forstand handler beherskelse av sjangeren samtidig om å tilegne seg og å gå inn i en skriftkultur. I det barnet lærer å kontrollere sjangeren, tar sjangeren samtidig kontroll over barnet. Sagt på en annen måte: Når vi bruker språk, blir andres tidligere bruk del av ytringen som et ekko i egen bruk, samtidig som ulike formuleringer av en ytring står mellom ytringer som kommer og de som har vært (Bakhtin, 1986).

I skrivesituasjonen vil elevene utforme tekstene med sjangeren både som verktøy og premissleverandør. Elevene gjør sine kreative valg i et spenningsfelt mellom individualitet og fellesskap, mellom den foreliggende situasjonen og tidligere erfaringer med gjenstander, tekster, situasjoner og deltakere. Forskjeller mellom elevers tekster vil i et mer retorisk orientert perspektiv bli

explained by seeing them as the expression of the different stances each student adopted to the recording of their experience of learning, their response to the protocol of 'being scientific', and their realization of this visually and linguistically, and the students' engagement with the recontextualized genres of schooled knowledge available to them in the task (Kress, Jewitt, Ogborn, og Tsatsarelis, 2001, s 132).

Elevenes tekster vil også være forskjellige fordi de bruker illustrasjoner forskjellig. Naturfagets tekster er ikke kun verbalspråklige. De er multimodale ved at de inneholder semiotiske moduser i form av ressurser som illustrasjoner, diagrammer, grafer og tabeller osv. Det multimodale perspektivet er utviklet gjennom en forlengelse av Hallidays teori til visuell semiotikk (Kress og Van Leeuwen, 1996). Dette åpner for transformasjon som en viktig side ved skriving: Ulike semiotiske moduser har sine unike styrker for meningsskaping, samtidig som tekstens mening realiseres også i hvordan ulike moduser virker sammen. Dette er et viktig aspekt ved naturfaglige tekster, som nettopp består av verbaltekst, grafer, tabeller eller illustrasjoner, og hvor forståelse nettopp innebærer at ulike moduser blir orkestrert på en adekvat måte i faglige problemområder.

IKT innebærer en betydelig utvidelse av tekstens multimodale karakter sammenlignet med trykte medier. Kress (2003) hevder at IKT endrer enkelte grunntrekk ved tekster ved at skjermen blir dominerende framfor arket. Mens arket var dominert av skriftspråkets grammatikk, så er skjermen orientert mot bildets grammatikk (Kress og Van Leeuwen, 1996). Der skriftspråket er orientert mot tid (teksten er laget for å leses sekvensielt), er skjermen orientert mot rom (alle elementene er tilgjengelig samtidig i forhold til hverandre). Mens det skrevne ord alltid må vise utover seg selv, ligner bildet på det som det skal representere, noe som gjør at bildet kan være umiddelbart ncervcerende på en måte ordet ikke kan (Kjeldsen, 2004). Kress knytter denne grunnleggende overgangen 
til en dannelsespolitisk forskyvning fra en ordnet fortid til en kompleks nåtid gjennom begrepet design. Poenget er ikke 'hva som ble gjort tidligere, hvordan og av hvem', men mer 'hva som trengs nå, i denne situasjonen med dette publikumet og disse ressursene, gitt mine hensikter og interesser'. Dette perspektivet vektlegger et retorisk element gjennom fokuset på individets utfordringer i situasjonen i en videre kulturell kontekst.

Samtidig som IKT utvider og utfordrer begreper både om tekst og dannelse, er IKT også et verktøy for å utvikle skrivekompetanse. Tekstbehandlingsprogram gjør det enkelt å endre egne tekster, både på setnings- og deltekstnivå. Bruk av læringsplattformer (LMS) og digitale mapper endrer skriveprosessene og kan gi økt skrivekompetanse (Erstad, 2004).

IKT endrer tekstpraksiser når kulturelle betingelser legger til rette for det. Det er imidlertid klokt å beholde fokuset på tekst og ikke fokusere for sterkt på den teknologiske løsningen for å vise eller spre tekster. Hvis vi regner med matematiske symbolspråk som en modus i multimodale tekster, så kan et tekstlig fokus i naturfag favne alle de grunnleggende ferdighetene nevnt i St.mld. 30.

Det sosialsemiotiske perspektivet til Kress vektlegger transformasjon av tekstlige ressurser som et tegn på læring (uten å foreskrive kvaliteten av læringen per se). Det må kunne innbefatte at elevens egne tekster blir ressurser for nye tekster som eleven skriver.

\section{Transformasjon av egne tekster}

I et mer kognitivt orientert perspektiv har Bereiter og Scardimalia påvist et skille mellom to ulike tilnærminger til skriving: Skrive for å fortelle kunnskap (knowledge-telling) og skrive for å omskape kunnskap (knowledge-transformation) (Bryson, Bereiter, Scardamalia, og Joram, 1991). I Bereiter og Scardamalia sin modell handler kompetent skriving om at problemer knyttet til innhold på den ene siden og retoriske problemer som handler om tekstens hensikter på den andre blir satt i sammenheng. En kyndig skriver håndterer begge områdene samtidig, slik at det som fortoner seg som spørsmål om innhold kan transformeres til spørsmål om retorikk og motsatt (Bryson, Bereiter, Scardamalia, og Joram, 1991). Dette er et særtrekk ved 'knowledge-transforming' i skriving. 'Knowledge-telling' knytter ikke de epistemologiske og retoriske områdene sammen som noe som må løses samtidig. Skriving blir i stedet å fortelle det en vet på en ganske lineær måte, fra start til slutt.

Sammenhengen til Kress sitt perspektiv ligger jo i transformasjonen; men forskjellen i perspektivene innebærer at den ene omhandler 'kunnskap', mens den andre fokuserer på 'semiotiske ressurser'; men denne forskjellen trenger ikke å bekymre oss her: Det viktige er at en prosess for å omskape og bearbeide tekster er en god forutsetning for utvikling av tekstkompetanse.

Vi skal i fortsettelsen diskutere dette aspektet ved skriving i naturfag, med oppmerksomhet særlig rettet mot labrapporten. Labrapporten har en sterk posisjon i naturfag. Det er en viktig aktivitet som tjener en rekke og til dels motstridende hensikter (Jenkins, 1999).

\section{LABRAPPORTEN I NATURFAG:}

\section{Skriving som taus eller eksplisitt kunnskap}

Et kvalitativt forskningsprosjekt som kombinerte klassromsobservasjoner, intervjuer og tekstanalyser av labrapporter i GK, videregående skole fokuserte på ulike aspekter ved rapportskriving, også elevene syn på skriving (Knain, under utgivelse). En del av prosjektet bestod i at elever etter å ha gjort en elevøvelse ble satt i grupper for å på grunnlag av sine individuelle rapporter lage en ny, 'beste' rapport. Hensikten med dette var å finne hvilke spørsmål som ble tatt opp i elevenes samtaler og hvilke aspekter ved rapportskriving som de fant grunn til å diskutere. 
Et gjennomgående og påfallende trekk ved diskusjonene var at elevene ikke fant grunn til å diskutere tekstkomposisjon, skrivemåter eller vurdere ulike formuleringer. Diskusjonene som oppstod, handlet om dataene som var samlet inn, hvorfor de avvek fra hverandre, og hvordan en skulle velge de som var de 'beste'. Skriveprosessen ble ikke fokusert, og når elevene validerte hverandres tekster mht. valg av hva som skulle stå i den felles rapporten, så ble kvalitetskriteriene underforstått. For eksempel sa en elev om det innledende avsnittet 'hensikt' at "X sin hensikt er god" uten å tydeliggjøre hva som menes med 'god'. Dette peker mot at det å lære å skrive labrapport i stor grad handler om normtilegnelse som taus kunnskap, men også at elevene mangler et metakognitivt språk for å snakke om labrapporten.

Yore, Hand og Prain (2002) finner denne dimensjonen når naturvitere snakker om sin egen fagskriving: de ser på skriving som et spørsmål om å informere og overtale et publikum; men har også mer tause og intuitive oppfatninger om at skriving bidrar til forståelse og til kunnskapskonstruksjon. De erkjente ikke at samtale om skriving var del av skriveprosessen. Hertzberg (1995) peker på det samme: På grunnlag av en gjennomgang hun har gjort av veiledninger for fagskriving og erfaringer fra kurs i tverrfaglig skriving konkluderer hun med at "det i norske akademiske miljøer generelt ser ut til å være liten bevissthet rundt tekstlige spørsmål” (Hertzberg, 1995, s 203).

Også i sin gjennomgang av og analyse av debatten mellom sjangerpedagogikk og ekspressiv skriving, konkluderer Hertzberg (2001) med at skriving for en stor del læres implisitt, gjennom de ulike faglige problemområdene. Hun viser blant annet til Freedmans studie. Freedman (1987) viste hvordan jusstudenter lærer å skrive i jussjangere gjennom å fornemme hva som kreves, og så gjennom det faglige fokuset, selve skriveprosessen og karaktersystemet utvikle skriveferdigheter. Dette skjedde vanligvis uten at kravene noen gang ble gjort eksplisitte, og om de ble undervist eksplisitt så ble ikke denne undervisningen funnet relevant av studentene.

Sjangerskolen vektlegger at det er sosio-økonomiske skillelinjer mellom hvilke elever som 'knekker' kodene inn mot naturfagets skriftkultur, og at det å la sjangrene være implisitte og 'usynlige' for elevene systematisk disfavoriserer under-priviligerte elever framfor andre. Hertzberg vektlegger kanskje i større grad at sjangerundervisning er viktig for elevenes metakognitive utvikling, at de gjennom det kan utvikle sin skrivekompetanse lengre enn om de fortsetter å være implisitte. Mine studier støtter negasjonen av dette: Elever som behersket skriving i labrapporter hadde ofte funnet en form som ikke utviklet seg, og som de ikke behøvde å reflektere over. Dette i kontrast til elever som ikke behersket strukturen, og som stadig ble forvirret og usikre i bruken av den.

Dette innebærer også en grunnleggende forskjell mellom ekspressiv skriving (Skrive for å Lære) og transaksjonell skriving (Lære å Skrive) ved at den transaksjonelle skrivingen vektlegger sosial kontekst på en helt grunnleggende måte. For å bli deltaker i en skriftkultur, så må elevene også mestre hvordan språket spiller sammen med situasjon (Pang, 2002). Ekspressiv skriving har kanskje et mer individuelt fokus, og kan dermed overse de sosiale praksiser som skriving inngår i (Guleff, 2002).

Denne normtilegnelsen er det viktig å få tak på. Hva kan den handle om? Det sosialsemiotiske perspektivet rommer en forståelse av sjanger forstått som tekstlige og sosiale normer som læres gjennom praksis. Det er imidlertid mange ideologier som virker styrende på naturfag. Analyser av naturviternes egne perspektiver på tekst og vitenskapssosiologiske studier kan også peke mot en annen motsetning som er særlig latent for labrapportens rolle: Skriving i skvis mellom arbeid med tekst som verktøy for ny erkjennelse på den ene siden, og et ideal om naturen som 'tar ordet' i en nøytral forskers eksperimentelle arbeid på den andre. Vi skal nedenfor konkretisere dette i forhold til naturens dobbeltrolle i naturvitenskapelige diskurser.

\section{Natur mot tekst?}

Spenningen omtalt i forrige avsnitt har å gjøre med at språket fungerer både sosialt og referensielt; vi snakker om virkeligheten samtidig som vi skaper kontakt med andre. Denne spenningen er på- 
pekt i sosiologiske vitenskapsstudier (Latour og Woolgar, 1979). Disse studiene har forårsaket uro omkring hvordan gyldig kunnskap forklares (Gross og Levitt, 1994). Men flere studier har pekt mot at naturen tar en dobbeltrolle i forhold til sosial praksis. Kanskje har Latour (1987) formulert dette aspektet klarest som forskningens janusansikt. Dette innebærer at naturen har to motstridende roller i forhold til frambringelse av kunnskap. Mens forskerne deltar i kontroverser på veien fra tentativ til etablert kunnskap er naturen resultat av kontroversene. Når derimot kunnskapen er etablert produkt, er naturen årsak til at kontroversen fikk en løsning.

Gilbert og Mulkay (1984) påviser noe av det samme i en studie som sammenligner hva forskere i en kontrovers i biokjemi omkring stoffet ATP sier i intervjuer og hva de skriver i artikler. (ATP er viktig for omsetning og lagring av energi i cellen.) De fant to språklige registre hos naturviterne som var involverte i kontroversen. Det ene var et 'contigent' register som vektlegger sosiale relasjoner og posisjoner, hvor individers preferanser har en rolle i kunnskapsutvikling. Det andre var det de kaller et 'empirisist' register. Her er naturviternes språk et nøytralt medium hvor empiriske fenomener gjør seg til kjenne gjennom eksperimenter. Først når fakta er etablert kan en se tilbake på hva det sosiale bestod i (Gilbert og Mulkay, 1984). Dette er helt i tråd med Gross (1990) som framhever den vitenskapelige artikkelen som gjenskaping av myten om naturvitenskap som induksjon. For eksempel er idealet om å gjøre det mulig for andre kompetente forskere å reprodusere eksperimenter på grunnlag av informasjonen i den vitenskapelige artikkelen skjøvet til side for andre og konkurrerende hensyn.

Den vitenskapelige artikkelen er en vesentlig arena for det epistemologiske skiftet som er trukket opp over, hvor den vitenskapelige artikkelen ikke står i noen enkel sammenheng med forskningsprosessen, verken epistemologisk, sosialt eller historisk (Swales, 1990). Gjennom den historiske utviklingen hvor utviklingen av naturvitenskapelig tekst tjente funksjonelle og retoriske hensikter for de tidlige naturviterne, så utviklet naturviterne et mønster for skriving som senere ble den dominerende normen for vitenskapelig skriving: IMRaD. IMRaD står for Introduction, Methods, Results and Discussion. Formatet ble bortimot enerådende i naturvitenskapelig publisering, og har også spredt seg til humaniora og samfunnsvitenskap. IMRaD har imidlertid fjernet seg fra sitt eksperimentelle opphav til å bli standard for naturvitenskapelige artikler generelt, og eksperimentell praksis har trådt i bakgrunn på bekostning av funksjonelle krav om standardisering, konsentrasjon og komprimering (Breivega, 2003). IMRaD er et grunnleggende uttrykk for vitenskapelighet, og er en norm og et ideal som ikke bare tjener ideologiske funksjoner i naturvitenskapen, men også viktige funksjoner i vitenskapelig kommunikasjon.

Kanskje er det dette spenningsforholdet som labrapporten rommer i skolen. Labrapporten er kanskje mer forbundet med å lære naturvitenskapelig metode enn naturvitenskapelig skriving i skolen. Dette, sammen med et syn på vitenskapelig prosess i lærebøker hvor den sosiale dimensjonen kun blir trukket fram når forskningen ikke fungerer slik den skal, altså at kunnskap frambringes gjennom anvendelse av vitenskapelig metode (Knain, 2001) peker mot iboende spenninger i naturvitenskapelig kultur som også finner veien til skolen. Det oppstår en konflikt i det å åpne labrapporten for et fokus på eksperimentets skriftlighet hvis labrapporten egentlig handler om å lære en idealisert og oppskriftsmessig vitenskapelig metode hvor resultater følger uproblematisk fra anvendelse av riktig prosedyre.

The unique grammatical forms, compact nature, and detached voice used in science writing have arisen due to the needs of the scientific community. As a by product of this process, the compressed language of science makes it seem as though reporting is a recapitulation of knowledge already known to the writer, when in fact, it is knowledge that has been negotiated and renegotiated many times previously through informal writing, peer group discussion, reading, and thinking. Therefore, the traditional four-part laboratory report with sections for purposes, methods, results and conclusions tends to obscure rather teach science learners how knowledge is developed and communicated in science (Wallace og Hand, 2004, s 68). 
Et verktøy for å øke elevenes bruk av labrapporten funksjonelt kalt The Science Writing Heuristic (SWH) er utprøvd i amerikanske skoler med positive resultater (Hand, Wallace, og Yang, 2004; Wallace og Hand, 2004). Poenget er å kunne arbeide med tilpasningen mellom sjangeroppsettet og situasjon, å skape en utvikling fram mot labrapporten, slik at den ikke kun blir en engangsskriving. Dette for å oppmuntre til skriving som knowledge-transformation og ikke kun knowledge-telling.

\section{IMRaD som ressurs i skriveopplæringen}

I tråd med teksttransformasjon som utgangspunkt for læringsaktiviteter og sjangeren som ressurs kan IMRaD dels gjøres til gjenstand for eksplisitt undervisning, dels fungere som støtte for elevenes egen skriving. Dette innbærer et delt fokus, både på sjangeren som ressurs og begrensning, og som norm og palett i skrivingen. Dels er den et mål for hvilken kompetanse elevene skal nå, samtidig er kompetansen lite verdt uten at eleven kan omforme sjangere i forhold til oppgaven eleven står overfor.

Et fokus på å lære om naturfaglig språk vil også kunne fokusere på IMRaD: Hva innebærer de ulike delene av forkortelsen? Hva er opprinnelsen historisk, og hvorfor fikk den slik gjennomslagskraft? Når brukes IMRaD, og for hvilke siktemål? Hvilke forskjeller og likheter har IMRaD med skolens labrapport? Hva stikker forskjellene i?

En mulighet er å utnytte at IMRaD faktisk brukes for skriving for mange formål, ikke bare i naturvitenskapen men også i andre fag. Flyum (2004) har laget en metode som kombinerer IMRaD med femavsnitts skisser, hvor IMRaD blir tilpasset til ulike skriveoppgaver og hensikter. Også labrapporten kan åpnes for skrivetrening på denne måten, for å fokusere på bestemte aspekter ved skriveoppgaven som delkompetanser med sikte på å utvikle et repertoar av strategier og tilnærminger som del av utvikling av funksjonell sjangerkompetanse.

\section{KONKLUSJONER}

Naturfagets sjangere er en viktig utfordring i skriveopplæringen. For det første er de viktige redskap og normer i yrker hvor naturvitenskap inngår. For det andre er kjennskap til sjangrene en viktig del av det å gjøre naturvitenskapelige skriftkulturer tilgjengelige for elever. For det tredje er de et historisk og kulturelt produkt som er del av verdenslitteraturen, og bør verdsettes som sakprosa. IMRaD kan være et viktig redskap for å lære om naturvitenskapelig språk, og naturvitenskapens historie og samfunnsforankring.

Skriving i naturfag vil handle om å balansere ulike hensyn; mellom å gi elevene støtte fra sjangere på veien til å lese og skrive i dem på den ene siden, og samtidig ikke bruke dem som ferdige sjablonger uten fokus på tilpasning til ulike hensikter og faglige problemområder. Et funksjonelt perspektiv på språk må forstå sjangrene både som del av naturfagets etablerte skriftkulturer, og som redskaper for elevers kreative og motiverte skriving i faglige problemområder. I vurderingsøyemed kan innsikt i hvordan tekster fungerer i undervisning og hva elever gjør i dem både faglig og kulturelt være en viktig ressurs for læreren for å forstå elevenes faglige problemer og ståsted i faget.

Både Skrive for å Lære og Lære å Skrive perspektivene er viktige for at naturfaglige sjangere skal læres gjennom prosesser hvor elever kan transformere egne og andre tekster til ny forståelse. Sjangrene læres for mange elever i stor grad implisitt gjennom arbeid med fagets problemområder, men elevene trenger også å arbeide eksplisitt med skriving for å utvikle denne kompetansen, slik at både retoriske og innholdsmessige sider ved skriving kan arbeides med gjensidig. Her kan Skrive for å Lære representere en mer allmennpedagogisk tilnærming i forhold til en mer fagdidaktisk orientert Lære å Skrive.

I de nye læreplanene er skriving en grunnleggende ferdighet som skal nedfelles i alle fag, også naturfag. Et mer overordnet fokus på tekst i naturfag kan favne alle de grunnleggende ferdighetene 
som læreplanene beskriver; å kunne uttrykke seg muntlig, å kunne lese, å kunne uttrykke seg skriftlig, å kunne regne, og å kunne bruke digitale verktøy. Det er også viktig at scientific literacy forstås som en multimodal kompetanse nært beslektet med andre 'literacies', deriblant 'digital literacy'.

Skriving har alltid vært en viktig del av både naturvitenskapen og skolens naturfag. Men et eksplisitt fokus på skriving vil gjøre at latente konflikter i forholdet mellom produkt og prosess og vitenskapelig metode kommer til overflaten i form av konflikter mellom kunnskapsutvikling i tekst og induktivistisk metode som ideologi.

\section{REFERANSER}

Bakhtin, M. M. (1986). Speech Genres \& Other Late Essays. Austin: University of Texas Press.

Berge, K. L. (2004). Skriftkultur. I Skriftkultur. Skrifter fra prosjektmiljøet Norsk Sakprosa Nr. 10, 5-13. Oslo: Norsk sakprosa.

Breivega, K. R. (2003). Vitskapelige argumentasjonsstrategiar. Ein komparativ analyse av superstrukturelle konfigurasjonar i medisinske, historiske og språkvitskapelige artiklar Nr. 8. Oslo: Norsk Sakprosa.

Bryson, M., Bereiter, C., Scardamalia, M., \& Joram, E. (1991). Going beyond the Problem as Given: Problem Solving in Expert and Novice Writers. I R. J. Sternberg \& P. A. Frensch (Red.), Complex Problem Solving. Principles and Mechanisms, 61-84. Hillsdale \& New Jersey: Lawrence Erlbaum Associates.

Cobern, W. W., \& Aikenhead, G. S. (1998). Cultural Aspects of Learning Science. In B. J. Fraser \& K. G. Tobin (Eds.), International Handbook of Science Education Vol. 2, pp. 39-52. Dortrecht: Kluwer Academic Publishers.

Connolly, P. (1989). Writing and the Ecology of Learning. I P. Connolly \& T. Vilardi (Red.), Writing to Learn Mathematics and Science, 1-14. New York \& London: Teachers College Press, Columbia University.

Erstad, O. (2004). Piloter for skoleutvikling. Samlerapport fra forskningen 2000-2003. Universitetet i Oslo: Forsknings- og kompetansenettverk for IT i Utdannin (ITU), Universitetet i Oslo.

Flyum, K. H. (2004). Femavsnitts metoden - en enkel arbeidsmåte for skriveundervisning i alle fag. Nedlastet 18.10.2004, fra http://folk.uio.no/khflyum/femavsnittsmetoden/Introduksjon.pdf

Freedman, A. (1987). Learning to Write Again: Discipline-Specific Writing at University. Carleton Papers in Applied Lanuage Studies, IV, 95-115.

Gilbert, G. N., \& Mulkay, M. (1984). Opening Pandora's Box. A sociological analysis of scientists discourse. Cambridge \& London: Cambridge University Press.

Gross, A. G. (1990). The Rhetoric of Science. Cambridge and London: Harvard University Press.

Gross, P. R., \& Levitt, N. (1994). Higher Superstition. The academic left and Its Quarrels with Science. Baltimore \& London: The John Hopkins University Press.

Guleff, V. (2002). Approaching Genre: Writing as Apprenticeship to Communities of Practice. I A. M. Johns (Red.), Genre in the Classroom. Multiple Perspectives, 211-223. New Jersey og London: Lawrence Erlbaum Associates.

Halliday, M. A. K., \& Martin, J. R. (1993). Writing Science. Literacy and Discursive Power. London og Washington, D. C.: The Falmer Press.

Hand, B. M., Wallace, C. W., \& Yang, E.M. (2004). Using a Science Writing Heuristic to enhance learning outcomes from laboratory activities in seventh-grade science: quantitative and qualitative aspects. International Journal of Science Education, 26(2), 131-149.

Hertzberg, F. (1995). Uttalte og uutalte normer for vitenskapelig skriving. I E. B. Johnsen (Red.), Virkelighetens forvaltere. Norsk Sakprosa, første bok. Oslo: Universitetsforlaget.

Hertzberg, F. (2001). Tusenbenets vakre dans. Forholdet mellom forkunnskap og sjangerbeherskelse. Rhetorica Scandinavia, 18, 92-105.

Jenkins, E. W. (1999). Practical work in School Science - some questions to be answered. I J. 
Leach \& A. C. Paulsen (Red.), Practical Work in Science Education, (s 19-32). Roskilde og Dordrecht: Roskilde University Press og Kluwer Academic Publishers.

Johns, A. M. (2002). Destabilizing and Enriching Novice Students Genre Theories. I A. M. Johns (Red.), Genre in the Classroom. Multiple Perspectives, (s 237-246). New Jersey og London: Lawrence Erlbaum Associates.

Keys, C. W. (1999). Revializing Instruction in Scientific Genres: Connecting Knowledge Production with Writing to Learn in Science. Science Education, 83(2), 115-130.

Kjeldsen, J. E. (2004). Retorikk $i$ vår tid. En innføring i moderne retorisk teori. Oslo: Spartacus forlag.

Knain, E. (2001). Naturfagets tause stemme. Diskursanalyse av loerebøker i Natur- og miljøfag. Oslo: Universitetet i Oslo.

Knain, E. (under utgivelse). Identity \& genre literacy in high-school students' experimental reports. International Journal of Science Education.

Knain, E., \& Flyum, K. H. (2003). Genre as a resource for science education: The history of the development of the experimental report. I K. Fløttum \& F. Rastier (Red.), Academic discourse. Multidisciplinary approaches, (s 181-205). Oslo: Novus Press.

Kress, G. (2003). Literacy in the New Media Age. London og New York: Routledge.

Kress, G., Jewitt, C., Ogborn, J., \& Tsatsarelis, C. (2001). Multimodal Teaching and Learning. The rhetorics of the science classroom. London og New York: Continuum.

Kress, G., \& Van Leeuwen, T. (1996). Reading Images. The Grammar of Visual Design. London og New York: Routledge.

Latour, B., \& Woolgar, S. (1979). Laboratory Life. The Social Construction of Scientific Facts (Vol. 80). Beverly Hills \& London: Sage Publications.

Lemke, J. L. (2001). Articulating Communities: Sociocultural Perspectives on Science Education. Journal of Research in Science Teaching, 38(3), 296-316.

Martin, J. R. (1993). Literacy in Science: Learning to Handle Text as Technology. I M. A. K. Halliday \& J. R. Martin (Red.), Writing science. Literacy and Discursive Power, (s 166-202). London \& Washington D. C.: The Falmer Press.

Norris, S. P., \& Phillips, L. M. (2003). How literacy in Its Fundamental Sense is Central to Scientific Literacy. Science Education, 87(2), 224-240.

Pang, T. T. T. (2002). Texual Analysis and Contextual Awareness Building: Comparison of Two Approaches to Teaching Genre. I A. M. Johns (Red.), Genre in the Classroom. Multiple Perspectives, (s 145-161). New Jersey og London: Lawrence Erlbaum Associates.

Prain, V. (2004). The Role of Language in Science Learning and Literacy. I C. S. Wallace, B. Hand \& V. Prain (Red.), Writing and Lerning in the Science Classroom (s 33-45). Dortrecht og Boston: Kluwer Academic Publishers.

Swales, J. M. (1990). Genre Analysis. English in academic and research settings. Cambridge og New York: Cambridge University Press.

Thier, M., \& Daviss, B. (2002). The New Science Literacy. Using Languge Skills to Help Students Learn Science. Portsmouth: Heinemann.

UFD. (2003-2004). Kultur for loering. St. mld. 30. Oslo: UFD

Valdermo, O., \& Eilertsen, T. V. (2002). En loeringsbevisst skole. Kristiansand: Høyskoleforlaget.

Wallace, C. S. (2004). Evidence from the Literature for Writing as a Mode of Science Learning. I C. S. Wallace, B. Hand \& V. Prain (Red.), Writing and Lerning in the Science Classroom, (s 9-19). Dortrecht og Boston: Kluwer Academic Publishers.

Wallace, C. S., \& Hand, B. (2004). Using a Science Writing Heuristic to Promote Learnig from Laboratory. I C. S. Wallace, B. Hand \& V. Prain (Red.), Writing and Learning in the Science Classroom, (s 67-89). Dortrecht og Boston: Kluwer Academic Publishers.

Wellington, J., \& Osborne, J. (2001). Language and literacy in science education. Buckingham og Philadelphia: Open University Press.

Wells, G. (1999). Dialogic Inquiry. Towards a Sociocultural Practice and Theory of Education. Cambridge: Cambridge University Press.

Yore, L. D., Hand, B. M., \& Prain, V. (2002). Scientists as Writers. Science Education, 86(5), 672-692. 